\title{
The Moderating Role of Sustainable Maintenance on the Relationship between Sustainable Manufacturing Practices and Social Sustainability: A Conceptual Framework
}

\author{
Norsiah Hami, Yousif Munadhil Ibrahim, Fadhilah Mat Yamin, Shafini Mohd Shafie, Susan \\ Sabah Abdulameer
}

\begin{abstract}
It appears that companies' interest in achieving economic returns has made them neglect the social effects of their activities. With this imbalance in sustainability performance that causes environmental pollution and social damage, there is an urgent need to strike social sustainability. Therefore, this study aims to achieve social sustainability (SoS) by providing a proposed framework that integrates sustainable maintenance (SMA) into sustainable manufacturing practices (SMPs). Effective adoption of SMPs and SMA has a significant positive influence on SoS. Nevertheless, there are limited studies conducted on integrating SMA into SMPs and how it could impact SoS. The theoretical contribution of the present study depends mainly on expanding existing knowledge about highlighting the moderating role of SMA on the relationship between SMPs and SoS
\end{abstract}

Keywords: sustainable manufacturing practices; sustainable maintenance; social sustainability

\section{INTRODUCTION}

In this time, social sustainability (SoS) has become a significant issue for researchers and practitioners. In fact, all companies have a great responsibility in caring for their employees and communities [1], as well these companies should add value to these communities to achieve SoS [2]. Achieving SoS leads to achieving economic and environmental sustainability [2,3]. Likewise, Magis and Shinn [4] confirmed that its recognition as a phenomenon featured from environmental and economic sustainability would lead to its clarification of their contribution and appropriate use. Also, companies can not address the challenges of sustainability without involving social associates or stakeholders [5]. However, SoS is neglected and not considered as significant as economic or environmental sustainability [6], as well as its study in

Revised Manuscript Received on April 19, 2019. College of Business, Universiti Utara Malaysia, Kedah, Sintok, 06010, Malaysia.

Yousif Munadhil Ibrahim, School of Technology Management and Logistics, College of Business, Universiti Utara Malaysia, Kedah, Sintok, 06010, Malaysia.

Fadhilah Mat Yamin, School of Technology Management and Logistics, College of Business, Universiti Utara Malaysia, Kedah, Sintok, 06010, Malaysia.

Shafini Mohd Shafie, School of Technology Management and Logistics, College of Business, Universiti Utara Malaysia, Kedah, Sintok, 06010, Malaysia.

Susan Sabah Abdulameer, School of Technology Management and Logistics, College of Business, Universiti Utara Malaysia, Kedah, Sintok, 06010, Malaysia.
Norsiah Hami, School of Technology Management and Logistics,

practical implementation is still missing [7, 8]. Therefore, this study is interested in studying of SoS to address the issue of research, which aims to produce a conceptual framework that helps companies improve their social performance.

The vital question that arises is about how to address the issue of research about the improvement of SoS. In this respect, sustainable manufacturing practices (SMPs) have not been widely studied and documented by researchers [911]. Moreover, several empirical evidences suggests that SMPs contribute to improve SoS [e.g. 12, 13-20]. Therefore, there is a necessary need to study SMPs as they will contribute to addressing the practical issue of SoS in the companies.

Furthermore, Amrina and Aridharma [21] pointed to the need to study sustainable maintenance (SMA). Zhang, Kim, Tee and Lam [22] stressed that literature in SMA is the most limited. Similarly, Ararsa [23] noted that studies on SMA are still in infancy. Additionally, Franciosi, Iung, Miranda and Riemma [24] and Pires [25] recommended through their systematic review that more research should be conducted on the impact of maintenance on SoS. Similarly, Sénéchal [26] suggested further investigation on the relationship between maintenance and SoS. However, many companies still do not have a full understanding of the importance of effective maintenance activities and their significant role in achieving SoS [27]. Therefore, there are two main reasons for investigating in SMA: first, theoretically, to bridge the gap in the literature and the second reason practically, because it will contribute to addressing the practical issue of $\mathrm{SoS}$ in the companies.

Indeed, companies that have an interest in SMPs are more inclined to adopt SMA [8, 23, 24, 27-33]. This is because they have the same goal of improving SoS. Besides, many studies have examined the relationship between SMPs and SoS [34-40]. However, SMA has not been given any consideration in their studies. Accordingly, to the best of the knowledge of the authors, surprisingly, the moderating effects of SMA are ambiguous and have not been closely studied in any previous study. This gap points to the need for a theoretical framework to investigate the moderating impacts of SMA on the relationship between SMPs and SoS Therefore, this study aims to encourage the companies to

Published By:

Blue Eyes Intelligence Engineering 
achieve SoS by providing a proposed framework that integrates SMA into SMPs.

The results of the current study are expected to benefit many aspects in different areas. Academicians will obtain a better perception of the importance of integrating SMA into SMPs to achieve SoS. Additionally, policymakers and top management in the companies will gain a better understanding of how to improve the SoS, based the focus on SMPs and SMA.

The present study contains two sections viz.; following this introductory section is Section 2, the conceptual framework which provides insights from empirical literature and conceptual framework about SMPs, SMA and SoS, followed by Section 3, which involve conclusions of this study.

\section{LITERATURE REVIEW AND CONCEPTUAL FRAMEWORK}

\section{Social Sustainability (SoS)}

Social sustainability (SoS) also called "social equity" or "People" [41]. It is relevant to the social and safety matter of sustainability [42], and its main focus is people [43]. SoS can be considered as the principle which guarantees for all the society has an equal way to opportunities and resources $[44,45]$. It is one of the most important dimensions of sustainability that was highlighted in the definition of Brundtland in 1987. WCED [46] reported it through the concept of "needs" and emphasised that the primary goal of development is to satisfy human aspirations and needs, besides, focus on meeting the needs of the present and the future. In addition, it needs to be framed in the companies according to the time and place in which they operate [47].

\section{Sustainable Manufacturing Practices (SMPs)}

SMPs have gained vital importance over the past few years. Adebanjo, The and Ahmed [48] noted that there is a growing interest worldwide in the implementation of sustainable management practices. Also, interest in sustainable practices has increased as a result of grown interest in sustainable manufacturing SM over the years [9]. In other words, SM plays a significant role in manufacturing companies, and SMPs contribute to creating the right environment for companies [49]. It is because of linking the operations and decisions of industrial companies to environmental and social factors related to their activities [50].

SMPs have become a required necessity expected from all industries [14], and companies should prefer to implement them [51], as they lead to overcoming the challenges, they face in the industry [52]. There is increasing pressure on companies in all sectors by society, clients and other stakeholders to apply SMPs [51]. These pressures came as a result of the environmental effects of manufacturing practices through the inefficient use of resources, increased emissions and wastes, posing a significant threat to the global ecosystem and the welfare of society [53]. Which led to awareness and interest in SMPs by manufacturers [54]. Accordingly, Despeisse [55] defined SMPs as "an action or set of actions improving the manufacturing system's environmental performance".

Previously, manufacturing companies focused on the volume of profits realized regardless of the environmental impact of their activities [53]. Whereas, at present, it is necessary to use environmentally friendly practices in manufacturing to eliminating their harmful effects on the environment [56]. In addition to minimising possible hazards while maintaining the success of the business [57], besides great social benefits [58]. Likewise, Al-Ashaab, Flores, Hernando Anta and Varro [53] noted that the adoption and continuous improvement of SMPs are achieving economic, social and environmental benefits. In other words, SMPs achieve efficiency in resources and responsibility towards society [59]. Therefore, the adoption of SMPs according to the product lifecycle perspective improves SP.

Depending on the perspective of the product life cycle, SMPs can be classified into four dimensions concerning the phase at which the practices are implemented. These dimensions include the sustainable product design, sustainable manufacturing process, sustainable supply chain management and sustainable end of life management [12, $18,31,60,61]$. Which it is considered the dimensions of SMPs in the present study. Hence, the product life cycle perspective is more appropriate for the companies when implementing SMPs.

\section{SMPs and SoS}

Generally, several studies have been conducted to examine the linkages between SMPs and SoS. AgudoValiente, Ayerbe and Salvador [39] investigated the relationship between social responsibility practices and corporate social performance in Spanish service and manufacturing industry using a sample of 416 managers. The result showed a significant positive relationship between social responsibility practices and corporate social performance. In a different study, Croom, Marshall and McCarthy [37] demonstrated that social sustainability orientation was positively related to advanced social sustainability practices. They investigated the relationship among social sustainability orientation, advanced social sustainability practices and operational performance in the service and manufacturing industry in the United States of America. Likewise, the findings of Vargas, Mantilla and Jabbour [36] in the service and manufacturing industry revealed that the adoption of social practices leads to improve the competitive advantage of companies. Literature as above shows mostly a significant positive relationship between SMPs and SoS. Thus, based on the arguments above and assumptions of stakeholder theory [62], which propose that some advantages, benefits, firms decisionmaking power should be taken away from shareholders and given to stakeholders [63], the following proposition is offered: SoS.

P1: SMPs have a significant positive relationship with 


\section{Sustainable Maintenance (SMA)}

These days, it is essential for academicians and practitioners to focus not only on the technical aspect of maintenance activities but as an integrated set of technical, economic, environmental and social and safety dimensions [64]. This is because the maintenance activities and breakdowns in industrial companies result in harmful emissions, waste, dangerous accidents and consumption of energy and resources [27]. While the adoption of SMA by companies will make a significant difference in the economic, environmental, social and safety and technical [24, 27, 65]. Likewise, additionally the economic and environmental dimensions, SMA included social and safety dimension and worked to achieve a balance among these three dimensions [31, 33, 66, 67]. Moreover, companies that interesting on sustainable manufacturing face a new challenge in their implementation of SMA [21, 31, 33, 6668]. This is because of the complexity of manufacturing practices and processes [69-72], the need to make changes in policies and procedures of maintenance, attention to environmental and social and safety aspects as well as financial aspects $[31,33,66,73]$, competition pressure in manufacturing [74] and the government regulations towards sustainable development in manufacturing [75]. However, in recent years, changes in manufacturing paradigms have forced companies and managers to recognise the changing role of maintenance regards sustainability [23, 31, 66, 67, 69-71, 76, 77]. Likewise, in recent few years, the importance of incorporating sustainability into maintenance function has been recognised $[26,64,75,78-80]$. This is due to it provides lost costs and energy consumed during the product lifecycle [81]. Therefore, it is necessary to adopt SMA by companies that follow a sustainability approach in their business.

Jasiulewicz-Kaczmarek $[31,66]$ and Stuchly and Jasiulewicz-Kaczmarek [33] defined SMA "as proactive maintenance operations striving for providing balance in social (welfare and satisfaction of operators and maintenance staff), environmental and financial (losses, consequences, benefits) dimensions". Whereas, this study defined SMA as all maintenance activities that support the sustainability of the company, through the reduction of environmental impact, the safety and social and safety welfare of employees, the implementation of technical factors at the highest possible level and reducing maintenance costs.

\section{SMA and SoS}

According to Ali, Kamaruzzaman, Sulaiman and Peng [82], the efficiency in maintenance tasks and activities comes through the selection of proper maintenance. Although studies on SMA and SP are limited [22, 83], studies in most case studies have confirmed that SoS is achieved through the choice of sustainable maintenance [29, 30, 75, 83-85]. Zhang et al. [22], who studied in the context of port infrastructures in Japan, explained that the use of technology in equipment maintenance has positive effects on the all of sustainability performance dimensions. Mahmood, Abdullah and MdFauadi [86] concluded that the implementation of maintenance and overall equipment effectiveness have a positive impact on economic development and the protection of the environment and social welfare in the Malaysian manufacturing companies. Therefore, based on the arguments above and assumptions of Natural Resource-Based View (NRBV) theory [87], which proposition that clean technology that encompasses a range of activities and processes undertaken by companies lead to achieving sustainable competitive advantage, creating value for shareholders and achieving sustainability [88], the following proposition is offered:

\section{P2: SMA has a significant positive relationship with SoS.}

\section{SMA as a Moderating Variable}

Indeed, after the Second World War and as a result of rapid technological developments in the manufacturing environment, maintenance was considered as significant enhance function to production, operations and manufacturing [76]. Similarly, Jasiulewicz-Kaczmarek [89], Jasiulewicz-Kaczmarek and Drozyner [90] and Fraser, Hvolby and Tseng [91] maintained that maintenance plays a critical role in industrial companies as a support function for manufacturing. Besides, to achieve the best possible performance of the company [92, 93], the strategies and objectives of maintenance and manufacturing should be integrated [73, 94, 95]. This integration helps manufacturing companies save on costs, time and resources [96], as well as achieving economic benefits and competitive advantages [97]. Therefore, in order for companies to continue, they must keep pace with the rapid development of manufacturing and maintenance paradigms.

The moving of the manufacturing paradigms towards sustainable development has led to a change in the maintenance paradigms towards of product lifecycle, which involves four phases [33, 66, 90, 98]. This is due to the trend toward SMPs [75]. From a practical perspective, each phase of the product life cycle must be supported by maintenance [31, 90], from product design to end-of-life [99]. These phases can be utilised to manufacturing equipment and manufacturing products $[28,29]$. In this regards, to illustrate and justify the new process of understanding maintenance, Takata introduced the term "maintenance value chain" [100]. This emphasis on the life cycle view of sustainable manufacturing has produced the redefinition of the task of maintenance as being "a prime method for life cycle management whose objective is to provide society with required functions through products while minimizing material and energy consumption" [100]. In the same vein, the role of maintenance in the phases of the product lifecycle leads to the availability and reliability of equipment, improve environmental efficiency, and achieve safety [29, 101-103]. Thus, maintenance plays a vital role in interacting with all phases of the product lifecycle within SMPs.

The success of sustainable manufacturing operations and practices in improving sustainability performance is achieved through their integration with maintenance activities [27, 85, 97, 104]. Similarly, SMA is considered as a facilitator of SMPs [28, 105], which will improve the 
sustainability performance of economic, environmental and social [24, 30, 104].Based on the discussion and the arguments in the above, it concludes that the impact of SMPs on SoS will be stronger if sustainable maintenance moderates between them. Accordingly, based on the arguments above and assumptions of NRBV theory the following proposition is offered:

P3: SMA positively moderates the relationship between SMPs and SoS.

In short, the proposed conceptual model of this study is formulated by combining the stakeholder theory and the NRBV theory. Meanwhile, the current study integrating SMA into SMPs to examine their effects on SoS, as depicted in Figure 1.

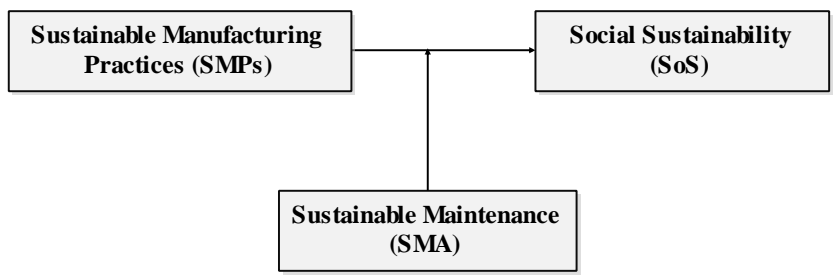

Fig.1.A conceptual framework for Social sustainability

\section{CONCLUSION}

The present paper offers a conceptual framework that investigates the moderating effect of SMA on the relationship between SMPs and SP. This research gap has been addressed in the present study. Previous empirical studies pointed out that there is evidence that adopting SMPs and SMA in companies improves SoS. The proposed conceptual framework in the current study will have some potential theoretical and practical implications. Firstly, as a contribution to the body of knowledge, academicians will obtain a better perception of the importance of integrating SMA into SMPs to achieve the SoS. Secondly, the practitioners in the companies can put in place SMPs and SMA framework, to achieve SoS. More clearly, the proposed framework will be necessary to policymakers and top management in the companies will gain them a better understanding of how to achieve SoS, based the focus on SMPs and SMA.

\section{ACKNOWLEDGMENT}

The authors wish to thank the Ministry of Higher Education Malaysia for funding this study under the Fundamental Research Grant Scheme (FRGS), and the Research and Innovation Management Centre, Universiti Utara Malaysia, Kedah for the administration of the study.

\section{REFERENCES}

1. Sobry, S.C., The relationship between green supply chain integration and sustainable performance. 2015, Universiti Utara Malaysia. Gas Supply Chain. 2014, University of Central Lancashire.

3. Yusuf, Y.Y., et al., The UK oil and gas supply chains: An empirical analysis of adoption of sustainable measures and performance outcomes. International
2. Abubakar, T., A Study of Sustainability in the Oil and

Journal of Production Economics, 2013. 146(2): p. 501514.

4. Magis, K. and C. Shinn, Emergent principles of social sustainability, in Understanding the social dimension of sustainability, J. Dillard, V. Dujon, and M.C. King, Editors. 2009, Routledge, Taylor \& Francis: UK. p. 1544.

5. Wilson, J.P., The triple bottom line: Undertaking an economic, social, and environmental retail sustainability strategy. International Journal of Retail \& Distribution Management, 2015. 43(4/5): p. 432-447.

6. Cuthill, M., Strengthening the 'social' in sustainable development: Developing a conceptual framework for social sustainability in a rapid urban growth region in Australia. Sustainable Development, 2010. 18(6): p. 362373.

7. Martínez León, H.C. and J. Calvo-Amodio, Towards lean for sustainability: Understanding the interrelationships between lean and sustainability from a systems thinking perspective. Journal of Cleaner Production, 2017. 142(Part 4): p. 4384-4402.

8. Garetti, M. and M. Taisch, Sustainable manufacturing: trends and research challenges. Production Planning \& Control, 2012. 23(2-3): p. 83-104.

9. Alayón, C., K. Säfsten, and G. Johansson, Conceptual sustainable production principles in practice: Do they reflect what companies do? Journal of Cleaner Production, 2017. 141: p. 693-701.

10. Despeisse, M., et al., The emergence of sustainable manufacturing practices Production Planning \& Control, 2012. 23(5): p. 354-376.

11. Roberts, S.J.F. and P.D. Ball, Developing a Library of Sustainable Manufacturing Practices. Procedia CIRP, 2014. 15: p. 159-164.

12. Abdul-Rashid, S.H., et al., The impact of sustainable manufacturing practices on sustainability performance: Empirical evidence from Malaysia. International Journal of Operations \& Production Management, 2017. 37(2): p. 182-204.

13. Gimenez, C., V. Sierra, and J. Rodon, Sustainable operations: Their impact on the triple bottom line. International Journal of Production Economics, 2012 140(1): p. 149-159.

14. Habidin, N.F., et al., Sustainable manufacturing practices, sustaining lean improvements and sustainable performance in Malaysian automotive industry. World Review of Entrepreneurship, Management and Sustainable Development, 2013. 9(4): p. 444-459.

15. Hami, N., M.R. Muhamad, and Z. Ebrahim, The Impact of Sustainable Manufacturing Practices on Sustainability. Jurnal Teknologi, 2016. 78(1): p. 139-152.

16. Zubir, A.F.M., et al., The development of sustainable manufacturing practices and sustainable performance in Malaysian automotive industry. Journal of Economics and Sustainable Development, 2012. 3(7): p. 130-138.

17. Shubham, P. Charan, and L.S. Murty, Organizational adoption of sustainable manufacturing practices in India: integrating institutional theory and corporate environmental responsibility. International Journal of Sustainable Development \& World Ecology, 2018. 25(1) p. 23-34.

18. Abdul-Rashid, S.H., et al., Drivers for the adoption of sustainable manufacturing practices: A Malaysia perspective. Int. J. Precis. Eng. Manuf.-Green Tech., 2017. 18(11): p. 1619-1631.

19. Hami, N., Sustainable manufacturing practice and sustainability performance mediated by innovation 
performance. 2015, Universiti Teknikal Malaysia Melaka.

20. Hartini, S. and U. Ciptomulyono, The Relationship between Lean and Sustainable Manufacturing on Performance: Literature Review. Procedia Manufacturing, 2015. 4: p. 38-45.

21. Amrina, E. and D. Aridharma. Sustainable maintenance performance evaluation model for cement industry. in 2016 IEEE International Conference on Industrial Engineering and Engineering Management (IEEM) 2016.

22. Zhang, Y., et al., Optimal sustainable life cycle maintenance strategies for port infrastructures. Journal of Cleaner Production, 2017. 142: p. 1693-1709.

23. Ararsa, B.B., Green Maintenance : A literature survey on the role of maintenance for sustainable manufacturing. 2012, Mälardalen University. p. 68.

24. Franciosi, C., et al., Maintenance for Sustainability in the Industry 4.0 context: a Scoping Literature Review. IFAC-PapersOnLine, 2018. 51(11): p. 903-908.

25. Pires, S. Industrial maintenance for sustainable performance: a systematic literature review. in The $23 \mathrm{rd}$ International Conference on Production Research. 2015.

26. Sénéchal, O., Research directions for integrating the triple bottom line in maintenance dashboards. Journal of Cleaner Production, 2017. 142: p. 331-342.

27. Liyanage, J.P. and F. Badurdeen. Strategies for integrating maintenance for sustainable manufacturing. 2010. London: Springer London.

28. Garetti, M., Maintenance for sustainable manufacturing, in The IMS M4SM MTP initiative, Manufacturing Technology Platform. 2011. p. 1-17.

29. Granados, M.H., Sustainable value creation in manufacturing through maintenance services, in Doctoral programme in management, economics and industrial engineering. 2014, Politecnico di Milano, Italy.

30. Ighravwe, D.E. and S.A. Oke, Ranking maintenance strategies for sustainable maintenance plan in manufacturing systems using fuzzy axiomatic design principle and fuzzy-TOPSIS. Journal of Manufacturing Technology Management, 2017. 28(7): p. 961-992.

31. Jasiulewicz-Kaczmarek, M., The role and contribution of maintenance in sustainable manufacturing. IFAC Proceedings Volumes, 2013. 46(9): p. 1146-1151.

32. Liyanage, J.P., Operations and maintenance performance in production and manufacturing assets: The sustainability perspective. Journal of Manufacturing Technology Management, 2007. 18(3): p. 304-314.

33. Stuchly, V. and M. Jasiulewicz-Kaczmarek, Maintenance In Sustainable Manufacturing. Scientific Journal of Logistics, 2014. 10(3): p. 273-284.

34. Bamgbade, J.A., A.M. Kamaruddeen, and M.N.M. Nawi, Malaysian construction firms' social sustainability via organizational innovativeness and government support: The mediating role of market culture. Journal of Cleaner Production, 2017. 154: p. 114-124.

35. Callan, S.J. and J.M. Thomas, Corporate financial performance and corporate social performance: an update and reinvestigation. Corporate Social Responsibility and Environmental Management, 2009. 16(2): p. 61-78.

36. Chacón Vargas, J.R., C.E. Moreno Mantilla, and A.B.L. de Sousa Jabbour, Enablers of sustainable supply chain management and its effect on competitive advantage in the Colombian context. Resources, Conservation and Recycling, 2018. 139: p. 237-250.

37. Croom, S., et al., Impact of social sustainability orientation and supply chain practices on operational performance. International Journal of Operations \& Production Management, 2018. 38(12): p. 2344-2366.

38. Marshall, D., et al., Going above and beyond: how sustainability culture and entrepreneurial orientation drive social sustainability supply chain practice adoption.
Supply Chain Management: An International Journal, 2015. 20(4): p. 434-454

39. Agudo Valiente, J.M., C. Garcés Ayerbe, and M. Salvador Figueras, Social responsibility practices and evaluation of corporate social performance. Journal of Cleaner Production, 2012. 35: p. 25-38.

40. Wang, H. and J. Choi, A New Look at the Corporate Social-Financial Performance Relationship:The Moderating Roles of Temporal and Interdomain Consistency in Corporate Social Performance. Journal of Management, 2013. 39(2): p. 416-441.

41. Elkington, J., Cannibals with Forks: The Triple Bottom Line of 21st Century Business. First ed. 1997: Capstone.

42. Wang, Z., et al., Composite sustainable manufacturing practice and performance framework: Chinese auto-parts suppliers' perspective. International Journal of Production Economics, 2015. 170(Part A): p. 219-233.

43. Frank, M., Dumbor , A.C. Nwuche, and S.A.C. Anyanwu, Operations management activities and organizational sustainability in oil and gas companies in rivers state. International Journal of Advanced Academic Research, 2016. 2(11): p. 34-56.

44. Bansal, P., Evolving sustainably: a longitudinal study of corporate sustainable development. Strategic Management Journal, 2005. 26(3): p. 197-218.

45. Kiewiet, D.J. and J.F.J. Vos, Organisational sustainability: a case for formulating a tailor-made definition. Journal of Environmental Assessment Policy and Management, 2007. 09(01): p. 1-18.

46. WCED, Our Common Future. 1987: Portland.

47. Boström, M., A missing pillar? Challenges in theorizing and practicing social sustainability: introduction to the special issue. Sustainability: Science, Practice, \& Policy, 2012. 8(1)

48. Adebanjo, D., P.-L. Teh, and P.K. Ahmed, The impact of external pressure and sustainable management practices on manufacturing performance and environmental outcomes. International Journal of Operations \& Production Management, 2016. 36(9): p. 995-1013.

49. Gupta, S., et al. Analytic Hierarchy Process (AHP) Model for Evaluating Sustainable Manufacturing Practices in Indian Electrical Panel Industries. in Proceedings of the XVIII Annual International Conference of the Society of Operations Management (SOM-14). 2015

50. Cerinšek, G., S.A. Petersen, and T. Heikura, Contextually enriched competence model in the field of sustainable manufacturing for simulation style technology enhanced learning environments. Journal of Intelligent Manufacturing, 2013. 24(3): p. 441-455.

51. Nordin, N., H. Ashari, and M.F. Rajemi, A Case Study of Sustainable Manufacturing Practices'. Journal of Advanced Management Science, 2014. 2(1): p. 12-16.

52. Yucel, E. and M. Gunay, An evaluation on machining processes for sustainable manufacturing. Gazi University Journal of Science, 2013. 26(2): p. 241-252.

53. Al-Ashaab, A., et al. A framework of industrial sustainability good practices. in Proceedings of the 11th International Conference on Manufacturing Research (ICMR2013). 2013. Cranfield University, UK.

54. Habidin, N.F., et al., The Relationship between Sustainable Manufacturing Practice and Environmental Performance in Malaysian Automotive SMEs. International Journal of Academic Research in Business and Social Sciences, 2016. 6(12): p. 338-352.

55. Despeisse, M., Sustainable manufacturing tactics and improvement methodology: A structured and systematic 
approach to identify improvement opportunities, in School of Applied Science. 2013, Cranfield University.

56. Nordin, N., H. Ashari, and M.G. Hassan. Drivers and barriers in sustainable manufacturing implementation in Malaysian manufacturing firms. in 2014 IEEE International Conference on Industrial Engineering and Engineering Management. 2014.

57. Abdullah, I., et al., Sustainable manufacturing practices in Malaysian palm oil mills: Priority and current performance. Journal of Manufacturing Technology Management, 2017. 28(3): p. 278-298.

58. Kibira, D. and C. McLean, Modeling and simulation for sustainable manufacturing. Proceedings of the 2nd International Association of Science and Technology for Development, 2008: p. 254-263.

59. Badurdeen, F. and I.S. Jawahir. Strategies for Value Creation Through Sustainable Manufacturing. in Proceedings of the 14th Global Conference on Sustainable Manufacturing. 2017. Stellenbosch, South Africa.

60. Millar, H.H. and S.N. Russell, The Adoption of Sustainable Manufacturing Practices in the Caribbean. Business Strategy and the Environment, 2011. 20(8): p. 512-526.

61. Russell, S.N. and H.H. Millar, Exploring the relationships among sustainable manufacturing practices, business performance and competitive advantage: Perspectives from a developing economy. Journal of Management and Sustainability, 2014. 4(3): p. 37-53.

62. Friedman, A.L. and S. Miles, Developing Stakeholder Theory. Journal of Management Studies, 2002. 39(1): $p$ $1-21$.

63. Stieb, J.A., Assessing Freeman's Stakeholder Theory. Journal of Business Ethics, 2009. 87(3): p. 401-414.

64. Bengtsson, M. and G. Lundström, On the importance of combining "the new" with "the old" - One important prerequisite for maintenance in Industry 4.0. Procedia Manufacturing, 2018. 25: p. 118-125.

65 . Jones, K. and J. Cooper. The role of routine maintenance in improving the sustainability of existing social housing. in roceedings of The European Network for Housing Research Conference Sustainable Urban Areas Rotterdam. 2007. he European Network for Housing Research.

66. Jasiulewicz-Kaczmarek, M. Sustainable Maintenance the next generation of maintenance management. in International Conference on Innovative Technologies, IN-TECH. 2013.

67. Jasiulewicz-Kaczmarek, M., Sustainability: Orientation in Maintenance Management-Theoretical Background, in EcoProduction and Logistics: Emerging Trends and Business Practices, P. Golinska, Editor. 2013, Springer Berlin Heidelberg: Berlin, Heidelberg. p. 117-134.

68. Jasiulewicz-Kaczmarek, M., Sustainability: Orientation in Maintenance Management: Case Study, in EcoProduction and Logistics: Emerging Trends and Business Practices, P. Golinska, Editor. 2013, Springer Berlin Heidelberg: Berlin, Heidelberg. p. 135-154

69. Jin, X., et al., The present status and future growth of maintenance in US manufacturing: results from a pilot survey. Manufacturing review, 2016. 3(10): p. 1-10.

70. Al-Turki, U.M., et al., Maintenance in Manufacturing Environment: An Overview, in Integrated Maintenance Planning in Manufacturing Systems. 2014, Springer International Publishing: Cham. p. 5-23.

71. Lee, J., et al. New thinking paradigm for maintenance innovation design. in Proceedings of the 19th World Congress The International Federation of Automatic Control. 2014. Cape Town, South Africa.

72. Jin, X., et al., Present Status and Future Growth of Advanced Maintenance Technology and Strategy in US
Manufacturing. International journal of prognostics and health management, 2016. 7(Spec Iss on Smart Manufacturing PHM): p. 012

73. Jasiulewicz-Kaczmarek, M. and A. Stachowiak Maintenance Process Strategic Analysis. in IOP Conference Series: Materials Science and Engineering. 2016.

74. Emmanouilidis, C. and P. Pistofidis. Machinery selfawareness with wireless sensor networks: a means to sustainable operation. in Proceedings of the 2nd workshop 'Maintenance for Sustainable Manufacturing'. 2010. Verona, Italy.

75. Ighravwe, D.E. and S.A. Oke, A multi-hierarchical framework for ranking maintenance sustainability strategies using PROMETHEE and fuzzy entropy methods. Journal of Building Pathology and Rehabilitation, 2017. 2(1): p. 9.

76. Baluch, N., Maintenance Management Performance of Malaysian Palm Oil Mills. 2012, Universiti Utara Malaysia.

77. Ratnayake, R.M.C. and T. Markeset, Technical integrity management: measuring HSE awareness using AHP in selecting a maintenance strategy. Journal of Quality in Maintenance Engineering, 2010. 16(1): p. 44-63.

78. Kayan, B.A., I.A. Halim, and N.S. Mahmud, Green maintenance for heritage buildings: low carbon repair appraisal approach on laterite stones. Chemical Engineering Transactions, 2017. 56: p. 337-342.

79. Sari, E., et al., Sustainable Maintenance Performance Measures: A Pilot Survey in Malaysian Automotive Companies. Procedia CIRP, 2015. 26: p. 443-448.

80. Iung, B. and E. Levrat, Advanced Maintenance Services for Promoting Sustainability. Procedia CIRP, 2014. 22: p. 15-22.

81. Nezami, F.G. and M.B. Yildirim. A framework for a fuzzy sustainable maintenance strategy selection problem. in Proceedings of the 2011 IEEE International Symposium on Sustainable Systems and Technology. 2011.

82. Ali, A.S., et al., Factors affecting housing maintenance cost in Malaysia. Journal of Facilities Management, 2010. 8(4): p. 285-298.

83. Pires, S., et al., An approach to the prioritization of sustainable maintenance drivers in the TBL framework. IFAC-PapersOnLine, 2016. 49(28): p. 150-155.

84. Sénéchal, O., Maintenance decision support for sustainable performance: problems and research directions at the crossroads of health management and eco-design. IFAC-PapersOnLine, 2016. 49(28): p. 85-90.

85. Sénéchal, O., et al. Sustainable performance: a paradigm inducing new needs of interoperability between maintenance and scheduling activities in manufacturing. in 5th International Workshop Advanced Cleaner Production. 2015

86. Mahmood, W.H.W., I. Abdullah, and M.H.F. MdFauadi, Translating OEE Measure into Manufacturing Sustainability. Applied Mechanics \& Materials, 2015. 761: p. 555-559.

87. Hart, S.L., A Natural-Resource-Based View of the Firm. Academy of Management Review, 1995. 20(4): p. 9861014.

88. Hart, S.L. and G. Dowell, Invited Editorial: A NaturalResource-Based View of the Firm:Fifteen Years After. Journal of Management, 2011. 37(5): p. 1464-1479.

89. Jasiulewicz-Kaczmarek, M., Integrating Lean and Green Paradigms in Maintenance Management. IFAC Proceedings Volumes, 2014. 47(3): p. 4471-4476.

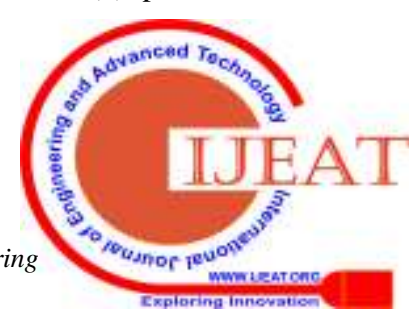


90. Jasiulewicz-Kaczmarek, M. and P. Drozyner, The Role of Maintenance in Reducing the Negative Impact of a Business on the Environment, in Sustainability Appraisal: Quantitative Methods and Mathematical Techniques for Environmental Performance Evaluation, M.G. Erechtchoukova, P.A. Khaiter, and P. Golinska, Editors. 2013, Springer Berlin Heidelberg: Berlin, Heidelberg. p. 141-166.

91. Fraser, K., H.-H. Hvolby, and T.-L. Tseng, Maintenance management models: a study of the published literature to identify empirical evidence: A greater practical focus is needed. International Journal of Quality \& Reliability Management, 2015. 32(6): p. 635-664.

92. Mostafa, S., et al., Lean thinking for a maintenance process. Production \& Manufacturing Research, 2015. 3(1): p. 236-272.

93. Mostafa, S., J. Dumrak, and H. Soltan, Lean Maintenance Roadmap. Procedia Manufacturing, 2015. 2: p. 434-444.

94. Graisa, M., An investigation into the need and implementation of Total Productive Maintenance (TPM) in Libyan cement industry. 2011, Nottingham Trent University.

95. Fredriksson, G. and H. Larsson, An analysis of maintenance strategies and development of a model for strategy formulation-A case study. 2012, Chalmers University Of Technology.

96. Moubray, J., 21st century maintenance organization part I: the asset management model. Maintenance technology, 2003. 16(2): p. 25-32.

97. Enofe, O.M. and G. Aimienrovbiye, Maintenance impact on Production Profitability-A Case Study. 2010, Linnaeus University.

98. Ait-Alla, A., et al., Real-time Fault Detection for Advanced Maintenance of Sustainable Technical Systems. Procedia CIRP, 2016. 41: p. 295-300.

99. Starr, A. and K. Bevis. The role of education in industrial maintenance: the pathway to a sustainable future. in Proceedings of the 4th World Congress on Engineering Asset Management. 2010. London: Springer London.

100. Takata, S., et al., Maintenance: Changing Role in Life Cycle Management. CIRP Annals - Manufacturing Technology, 2004. 53(2): p. 643-655.

101. Levrat, E., B. Iung, and A. Crespo Marquez, Emaintenance: review and conceptual framework. Production Planning \& Control, 2008. 19(4): p. 408-429.

102. Cunha, P.F., J.A.C. Duarte, and L. Alting, Development of a Productive Service Module Based on a Life Cycle Perspective of Maintenance Issues. CIRP Annals, 2004. 53(1): p. 13-16.

103. Tousley, P.C., Maintain it and save Why We Need Maintenance Management Programs. Energy Engineering, 2010. 107(5): p. 64-75.

104. Franciosi, C., A. Lambiase, and S. Miranda, Sustainable Maintenance: a Periodic Preventive Maintenance Model with Sustainable Spare Parts Management. IFACPapersOnLine, 2017. 50(1): p. 13692-13697.

105. IMS2020, Roadmap on Sustainable Manufacturing, Energy Efficient Manufacturing and Key Technologies, in Intelligent Manufacturing Systems (IMS) Program. 2010, European Commission.

\section{AUTHORS PROFILE}

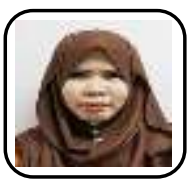

Norsiah Hami is an academic staff in the School of Technology Management and Logistics (STML), Universiti Utara Malaysia (UUM). She obtained her PhD in Manufacturing Engineering from Universiti Teknikal Malaysia Melaka, MSc (Technology Management) from UUM and Bachelor of Technology Management from UUM. She is a passionate researcher in the area of sustainability and innovation management, particularly the sustainable manufacturing practices and sustainability performance. Besides, the interest in operational excellence also extends her involvement in various consultation projects with government agencies and private firm. In STML, she teaches various courses such as innovation and commercialization management, industrial engineering, project paper, engineering drawing and interpretation, production and operations management, and mathematics, along with supervision of research at undergraduate and post graduate levels

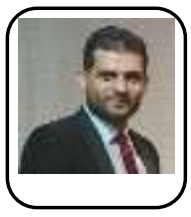

Yousif Munadhil Ibrahim is a $\mathrm{PhD}$ student at Universiti Utara Malaysia. Besides, his area about sustainable manufacturing practices, sustainable maintenance, and sustainability performance.

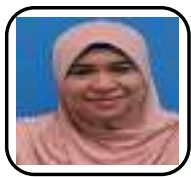

Fadhilah Mat Yamin is a senior lecturer at the Department of Technology Management, School of Technology Management \& Logistics, Universiti Utara Malaysia. She holds a PhD in the field of Technology Management from USM and MSc in Information Technology from UUM. Prior, she obtained his bachelor's degree in information technology also from UUM. As an academician, she teaches mainly course on ICT. Apart from teaching, she has been active in research relating to the areas of Sustainable ICT related issues like; Managing e-Technologies for competitive advantage, Green ICT \& Application, e-Skill etc. To date, Dr. Fadhilah also actively involved in several research grant. She is a member of several professional organizations and active as committee members for several international conferences

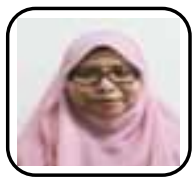

Shafini Mohd Shafie is an academic staff in the School of Technology Management and Logistics (STML), Universiti Utara Malaysia (UUM). She obtained her PhD in Renewable Energy from Universiti of Malaya, master's in electrical electronic from University Technology Malaysia and Degree in Electrical Electronic from University of Surrey. She is a passionate researcher in the area of renewable energy, biomass energy, life cycle assessment (LCA), energy efficiency and fuel cell development. She also publishes in various Scopus and ISI journal index related to hers research area and present her research in National and International conference. In STML, she teaches various courses such as electrical and electronic engineering, electrical resources and facilities, green electrical energy, electronic manufacturing, engineering science, electronic communication system and project paper, along with supervision of research at undergraduate and post graduate levels

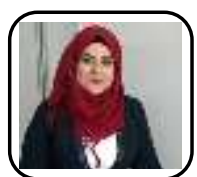

Susan Sabah Abdulameer is a $\mathrm{PhD}$ student at Universiti Utara Malaysia. Besides, her area about leagile supply chain strategy, information sharing, and supply chain performance. 